\title{
Our Own Devices: Heterotopic Communication, Discourse, and Culture in the Information Society 1
}

\author{
Leah A. Lievrouw \\ Department of Library and Information Science, University of California, Los Angeles, \\ California, USA
}

The main premise of this article is that in information societies generally, and in virtual social contexts particularly, a distinctive style of interaction to facilitate the communication of difference, heterotopic communication, has emerged. It rests on two cultural foundations: an ideological belief in the positive, socially integrating power of communication, and a prevailing ethic of instrumental rationality, subjective individualism, and strategically practiced self-interest. The former is demonstrated by the use of simulation and spectacle as sources of information; exhibitionism/voyeurism as a communicative style; and the awareness of surveillance. The latter is seen in the competitive use of knowledge as a commodity; a surface globalism masking deep parochialism; lateral as well as vertical infor mation inequity; and the use of public versus private as strategies for engagement rather than as spaces. Those who engage in heterotopic communication resort to their "own devices" both in the sense of personal agendas, strategies, interests, and interpretations, and in the form of the telecommunication tools that help realize them. These personal and technological devices allow individuals with the right educational and technical resources to avoid exposure to disagreement, difference, or other information that does not serve their direct purposes or reflect their particular views of the world; yet they also help convey the appearance of openness, availability, and cooperation. This style of interaction is used strategically in combination with infor mation and communication technologies to gain social or economic advantages, but

Received 13 December 1996; accepted 18 March 1997.

Earlier versions of portions of this paper were presented to the annual meetings of the Society for Social Studies of Science, New Orleans, LA, October 1994, and of the International Communication Association, Albuquerque, NM, May 1995. The author also acknowledges the very helpful comments of several faculty members of the Communication Studies Program at UCLA and of anonymous reviewers.

Address correspondence to Leah A. Lievrouw, University of California, Department of Library and Information Science, Los Angeles, 216 GSE\&IS Bldg., Box 951520, Los Angeles, CA 900951520, USA. E-mail: 1lievrou@ucla.edu it may encourage social separatism and parochialism, inhibit the negotiation of disputes, and emphasize competing interests.

Keywords communication and culture, communication technology, discourse, heterotopic communication, information society, social theory, virtual culture

In recent decades the term "information society" has become a widely used shorthand for complex social, economic, and institutionalchanges related to the proliferation of information and communication technologies. Researchers continue to debate whether the term stands for fundamental social change or merely the extension of the principles of industrial capitalism into new areas of society (Beniger, 1986; Hepworth \& Robins, 1988; Slack \& Fejes, 1987; Garnham, 1990; Webster, 1995). But the term is used uncritically in the mainstream media, and has caught on in the popular imagination.

People in self-styled information societies attempt to make sense of the growing importance (or at least visibility) of information and communication in everyday life. We engage with each other across time and space using a seemingly endless proliferation of high-tech gadgets, in a cultural context dominated by the financial and political power of organizations that proffer consultancy, expertise, networking, healing, wealth, entertainment, or other kinds of "software." Some observers argue that the prevalence and use of new information and communication technologies (ICTs) has fostered a new social milieu, sometimes referred to as virtual community or culture (Rheingold, 1993; Stone, 1992, 1995; Doheny-Farina, 1996; Jones, 1996).

The main premise of this article is that in information societies generally, and in virtual social contexts particularly, 
TABLE 1

Characteristics of interaction and discourse associated with communication ideology and instrumental rationality in heterotopic communication

\begin{tabular}{lc}
\hline \multicolumn{1}{c}{ Communication ideology } & \multicolumn{1}{c}{ Instrumental rationality } \\
\hline $\begin{array}{l}\text { Simulation/spectacle as information } \\
\text { sources }\end{array}$ & $\begin{array}{c}\text { Competitive use of information as a } \\
\text { commodity }\end{array}$ \\
$\begin{array}{l}\text { Exhibitionism/voyeurism as a } \\
\text { communicative style }\end{array}$ & Surface globalism vs. deep parochialism \\
Awareness of surveillance & Lateral and vertical information inequity \\
\hline
\end{tabular}

a distinctive style of interaction, heterotopic communication, has developed. It rests on two cultural foundations: an ideological belief in the positive, socially integrating power of communication, and a prevailing ethic of instrumental rationality, subjective individualism, and strategically practiced self-interest. The former is expressed in the use of simulation and spectacle as sources of information; exhibitionism/voyeurism as a communicative style; and the awareness of surveillance. The latter is seen in the competitive use of knowledge as a commodity; a global perspective masking deep parochialism; lateral as well as vertical information inequity; and the use of public versus private as strategies for engagement rather than as spaces (see Table 1).

In heterotopic communication, we resort to our "own devices" both in the sense of our personal agendas, strategies, interests, and interpretations, and of the ICT tools that help us realize them. Our personal and technological devices allow those of us with the right educational and technical resources to avoid exposure to disagreement, difference, or other information that does not serve our direct purposes or reflect our individual views of the world, yet they also let us convey the appearance of openness, availability and cooperation. We can use honesty or selfdisclosure and employ interactive information technologies strategically to gain social or economic advantages while presenting a collaborative face to others. Heterotopic communication protects us from the encroachment of "data smog" (Shenk, 1997), but it may also encourage social separatism, inhibit the negotiation of disputes, and emphasize our competing interests, while we maintain the appearance of communication and joint action.

In the remainder of this essay I discuss heterotopic communication, drawing on selected ideas from the research literature and criticism of information societies to frame a series of insights about the ways that the communication ideology and instrumental rationality/self-interest are reflected in contemporary interpersonal interactions and larger social discourses (of both the real and virtual sort). Each characteristic of heterotopic communication is briefly described, and some of the possible implications are suggested. Because this article is an attempt to synthesize a wide range of issues in a very limited space, some points are not as fully developed as might be desirable. Nonetheless, it is offered as a starting point for further exploration and theorizing. I conclude by suggesting several hypotheses for future study.

\section{DEFINITIONS}

The term heterotopic communication, from the Greek for "different places," is adapted from Foucault's notion of heterotopias: "other spaces" created as "countersites" to the rest of a given culture (Foucault, 1986). These siteswhich are not tied to physical space or proximity - are

a kind of effectively enacted utopia in which the real sites, all the other real sites that can be found within the culture, are simultaneously represented, contested, and inverted. Places of this kind are outside of all places, even though it may be possible to indicate their location in reality. (p. 24)

Foucault outlines five principles related to heterotopias: First, all cultures create and constitute them; second, a society can change the function of a given heterotopia according to its time and place; third, a heterotopia can juxtapose several incompatible sites simultaneously in a single real place; fourth, heterotopias are linked to certain "slices" of time, or heterochronies; and fifth, heterotopias may "open" and "close" in way(s) that "both isolates them and makes them penetrable" (p. 26). Though Foucault used theater and cinema as his principal examples, the description seems to apply equally well to the experience of communicating via the World Wide Web, MUDs and MOOs, mail lists, virtual reality, and other new media (e.g., see Turkle, 1996; Stone, 1992, 1995).

The term also echoes Bakhtin's notion of heteroglossia, which according to the "Glossary" of The Dialogic Imagination (Bakhtin, 1981, 428), is

The base condition governing the operation of meaning in any utterance. It is that which insures the primacy of 
context over text. At any given time, in any given place, there will be a set of conditions - social, historical, meteorological, physiological - that will insure that a word uttered in that place and at that time will have a meaning different than it would have under any other conditions.

Though Bakhtin's level of analysis differs from Foucault's - one examines individual speech, the other sites of cultural action - both heterotopias and heteroglossia are about the communication of difference, whether of meaning or of place. Heterotopic communication is a framework for analyzing the communication of difference that broadly reflects both ideas and levels of analysis.

Heterotopic communication also aligns with Stuart Hall's dual definition of culture (1986): first, that culture is the way that people in a given society understand ideas and ascribe meaning to everyday life: "[this view] relates 'culture' to the sum of the available descriptions through which societies make sense of and reflect their common experiences. . . 'culture' is itself democratized and socialized. . . 'culture', in this special sense, is 'ordinary' "' (1986, p. 35). Second, culture involves the cultural practices of people in that society (including the demarcation and representation of cultural sites through discourse). The second meaning is inseparable from the first; that is, to understand practices, we must also understand the ideas behind them - to understand social formations or sites we must also understand the meanings attributed to them.

I also use discourse in two senses, as the interpersonal exchange of ideas, and as the social formations and relationships that support and are produced by those exchanges. For example, it is possible to consider marital discourse in a conversation between a husband and wife, but also in the larger legal, moral, and social expectations surrounding the institution of marriage. Or the discourse of technology can be observed in the routine exchange of e-mail messages, but also in the larger infrastructure policies, engineering practices, and economic assumptions underlying the Internet.

\section{HETEROTOPIC COMMUNICATION AND VIRTUALITY}

Though heterotopic communication is becoming a common feature of interaction and discourse throughout information societies, it seems especially notable in virtual social forms and relationships, that is, those in which people "delegate their agencies to body representatives that exist in marginal spaces" (Stone, 1995, p. 121). As one "webmistress" describes it, "what's there and you can see is reality. What's there and you can't see, is transparent. What isn't there and you can see, is virtual" (Psaros, personal communication, 1997). The features of virtuality that are most important to interaction and discourse are that the communicator's presence and presentation of self or identity in an intangible and fluid network of social links take precedence over his or her proximity to others in physical space. As Druckrey (1996, p. 20) puts it, virtual interaction/society are experienced as

a kind of distributed embeddedness - or better, immersion -of the self in the mediascapes of teleculture, which must generate a communicative practice, whose boundaries are mapped in virtual, transitory networks, whose hold on matter is ephemeral, whose position in space is tenuous, and whose agency is measured in acts of implication rather than mere coincidences of location (emphasis in the original).

The natural mutability of social networks, enhanced by the switching capability of new ICTs, lends itself to the formation of many "other spaces" around our particular interests - we construct virtual realities, virtual worlds, virtual communities using our own "devices."

Virtual social forms, then, may tend toward segmentation and segregation of interests when we can make, break, and remake network ties more easily via new media than might be possible face to face or in close physical proximity. This tendency may help explain why virtual communities generally have not been the basis for broad-based political or social movements. As Jones (1995, p. 22) points out, "CMC...rarely functions to produce solidarity." Since people tend to create and maintain hierarchies and boundaries via new media just as they do in other aspects of social life, he says,

it is difficult to understandjust how hierarchy and community can coexist in CMC.... A common denominator linking hierarchy and community is identity.... CMC provides ample room for identity, but not for its fixing or structuring. (Jones, 1995, p. 30)

Presently, virtual culture appears to be a collection of many disparate sources and sites connected by transient links, an arrangement that promotes social and cultural differentiation rather than integration or collective sensibility or action. We navigate this shifting social environment using our personal identities or self-presentation as a "course" and heterotopic communication to work around around differences and variability. An overview of key themes in the research literature on information societies suggests that many features of this varied cultural landscape appeared well before "virtuality" was commonplace.

\section{FOUNDATIONS OF HETEROTOPIC COMMUNICATION IN INFORMATION SOCIETY RESEARCH}

The research literature exploring the presumed or anticipated shift from industrial to information society is now several decades old. Most early studies focused on economic and technological factors as evidence, either to 
support the claim of a new society (e.g., Machlup, 1962; Bell, 1973; Porat \& Rubin, 1977; Nora \& Minc, 1980; Masuda, 1981), or to maintain that such developments represented the latest phases of late-stage industrial capitalism (e.g., Slack \& Fejes, 1987; H. I. Schiller, 1987; Robins \& Webster, 1988; D. Schiller, 1988; Mosco \& Wasko, 1988; Hepworth \& Robins, 1988; Lyon, 1988; Garnham, 1994). Some observers noted that phenomena with their roots in industrialism seemed to be evolving into new forms (e.g., globalization, the commoditization of information, political participation, or surveillance). Others argued that the main institutionalforms of the information society, its economic relations and its technological history, were carryovers from industrialism (e.g., the rationalization or Taylorization of work; corporate and bureaucratic forms of organizing; the compartmentalization of work and leisure, public and private lives; the nuclear family as the ideal). The contrasting views have been labeled the "discontinuity" and "continuity" perspectives, respectively, though both focus on somewhat similar sets of economic and technological assumptions and data (Schement \& Lievrouw, 1987; Shields \& Samarajiva, 1993; Webster, 1995).

The industrial/informational, continuity/discontinuity dichotomy is paralleled in social and cultural theory generally by the ongoing debate over whether postmodernity has succeeded modernity as the dominant cultural form in developed societies. Broadly, modernity refers to social forms and cultural practices (including technology) that express and reify the liberal Enlightenment values of rationality, progress, individualism, objectivity, empiricism, efficiency, logic, equity, a predisposition toward change, the systems perspective, and so forth (Giddens, 1990; Haferkamp \& Smelser, 1992; Alexander, 1992). Postmodernity denotes a newer sensibility involving subjectivity, randomness, arationality, reflexivity, the shrinking or collapse of distance and time, relativism, and so on. The two differ epistemologically and ontologically, and therefore would tend to produce different types of interaction and discourse based on their respective sets of values and beliefs about the world.

Daniel Bell, in The Cultural Contradictions of Capitalism (1976), was one of the first theorists to address explicitly the cultural changes associated with the shift from industrialism toward an information economy. His work, and the responses of some of his critics, illustrate several important themes about social life and ICTs that continue to be problematic today. Bell alleged that modernity has been "exhausted" by tensions among the technoeconomic, polity, and culture realms of society, and he looked forward to a cultural renewal in postindustrialism, in the form of the "public household" that would retain the liberal focus on both individual achievement and market forces.
Subsequent writers, however, found problems with Bell's scheme. Calling him "the most brilliant of the neoconservatives," Habermas (1983, p. 6) argued that Bell blames modern culture for social problems and beliefs that actually stem from capitalism, and that Bell's rejection of modernism and promotion of capitalism, under the postindustrialor postmodern rubric, is really a strategy for reviving a premodern authoritarianism and reaction while preserving the social relations and privileges of a capitalist economic system. Poster (1990, p. 27) criticized Bell's privileging of the market, particularly the establishment of a market for information, "reversing a longstanding liberal principle that, in a democracy, knowledge and information in general must be freely accessible. [...] Bell sees fit to authorize the restriction of information to those who can foot the bill."

Bell's treatment of information/knowledgeas a commodity exchanged in a totalizing postindustrial social frame, rather than as shared action and understanding, leads him to see information "as an economic rather than a linguistic fact" (Poster, 1990, p. 28) and therefore to disregard the role of individuals' interactions in the continual remaking of culture. Instead, Poster proposed the "mode of information" as a defining characteristic of contemporary culture, in which social relations and discourse are actually transformed by the introduction of electronic communications and information technologies. The mode of information in a culture is situated, and must be studied, Poster says, at the level of language and discourse.

Stehr and Ericson (1992) make much the same point about Bell from the perspective of sociology of knowledge. Postindustrialism, they say, is predominated by a concern with the movement of vast quantities of commodified data,

But every society has to transmit information. Less, or very little, is said about the genesis and/or the substance of information, for example, the essentially contested character of information, the media of communication, especially human ones, or the reasons for the demand for, and changes brought about by, the contents of the information which is communicated. (emphasis in the original; Stehr \& Ericson, 1992, p. 8)

Moreover, they argue, discussions of the information society or postindustrial society generally treat knowledge itself (and, by implication, its knowers) as a black box-looking at the consequences or effects of knowledge/information in society rather than at the phenomenon of knowledge itself. Stehr and Ericson propose the construct of "knowledge societies" based on more grounded investigations of social and cultural action.

In a subsequent work, Stehr (1994) describes the "texture of knowledge societies," especially what he calls the "extension of the capacity to act" (p. 233) gained by individuals and small groups through their increased knowledge and use of information technologies. This permits 
individuals and small groups to withdraw from institutional involvement, and so tends to diminish institutional influence (e.g., government; Stehr discusses current debates about the "governability" of developed societies). Withdrawal contributes to social fragility in general and the "heightened contingency of social relations" (p. 259).

Though it is seminal, the debate surrounding postindustrialism is only a small part of the body of research and criticism examining the cultural changes associated with ICTs. Other writers concerned with the psychological, sociological, or political effects of information technology have contributed useful insights or constructs, such as information overload (Klapp, 1986), the undermining of information as a public good (H. I. Schiller, 1987), access to information (Cherry, 1985), the proliferation of indirect social relationships via new media (Calhoun, 1991, 1992), or the dislocation or "distribution" of the self (Meyrowitz, 1985; Gergen, 1991). Specific arenas such as political participation (Winner, 1977; D. Schiller, 1988; Tehranian, 1990; Doctor, 1992; Lievrouw, 1994), education (Williams et al., 1987; Postman, 1992), or urban centers (Dutton et al., 1987; Castells, 1989; Graham \& Marvin, 1996; see also Berleur et al., 1990) have also been examined.

The information society literature spans many disciplines and perspectives and cannot be summarized simply here. However, even this limited overview reveals important themes that continue to inform contemporary views about information society and its expression in virtual social contexts: the commoditization of information versus contextualized knowledge; individual agency versus mainstream social institutions; and issues of self and identity, globalization, surveillance, and social participation and equity. Scholars today recognize that studies are moving from the economic and technological, whole-society characterizations that dominated the early literature to examinations at the level of action (language and discourse). Nor is it enough to say that "information" or "knowledge" in the abstract is somehow being generated and moved, as other commodities are; the content and contingent meanings of knowledge must also be accounted for. If our interpersonal and small-group interactions are the principal sites of cultural production and action, they must be understood as contested and subject to the changing needs and perceptions of the participants.

Two organizing principles, the communication ideology and instrumental rationality/self-interest, help to relate these diverse themes and perspectives into the framework of heterotopic communication. Each principle involves several important characteristics of contemporary interaction and discourse. The two principles and the characteristics associated with them are illustrated in Table 1.

\section{THE COMMUNICATION IDEOLOGY}

A common leitmotif of contemporary American culture (often caricatured in the popular media) is our belief in the positive social power of communication, and our corresponding desire to appear open and communicative. ${ }^{2}$ We believe that communication and its attendant technology promote social integration and community, and are the key to easing conflict and the universal solvent for social problems. Communication itself has become a social virtue: We must maintain the appearance of communicativeness regardless of whatever real differences may exist among us. This is suggested by what Dan Schiller has called "the UNESCO fallacy" - that once people with apparently diverse and even contradictory interests encounter and interact with one another, they will naturally recognize their overarching mutual similarities and negotiate their conflicts (Schiller, personal communication).

In everyday life all kinds of social relations are cast as fundamentally communicative and subject to the extensions and improvements of information and communication technology. More communication (and therefore, technology) is good; less is not only bad - it is dis-integrating. The popular belief in communication as an allpurpose resolver of disputes is essentially ideological, that is, accepted uncritically as a "natural" or common-sense way of relating to others and seeing the world. Accordingly, we think of the information society as good insofar as it fosters new technologies that cultivate openness to communication and information exchange.

Researchers and scholars have problematized and studied communication in every aspect of social relations. Communication research was established as an academic discipline distinct from sociology and social psychology during the same period that mass and then telecommunication media developed and diffused across cultures (Rogers, 1994). The field focuses not only on communication technologies, but takes an increasingly integrated view encompassing technological, interpersonal, and rhetorical processes. Similarly, organizational studies and management have shifted from a structural, authority-based approach to the human relations and more recently to the organizational culture perspectives. Management styles now emphasize communication and cooperation among various levels of organizationalworkers (Euske \& Roberts, 1987). Communication is also central in clinical psychology and counseling, which has influenced aspects of daily life ranging from education, child rearing, and religion to law enforcement and health care. The New Age and selfhelp movements have made effective interpersonal communication skills a prerequisite for personal and social progress. And politics in the United States is so preoccupied with communication and image (via the press or consciously devised campaigns, or "spin"), critics charge, 
that the actual work of political negotiation and governing may have been seriously compromised.

Perhaps the source of the communication ideology can be traced to the emergence of communication/information technologies as the central or master metaphor for developed societies. The identification of a society with its key technologieshas a long social history (e.g., Innis, 1950); in recent decades the mass media and then computers have filled this role (Carey, 1989). Early discussions of the information society tended to highlight individual technologies, like satellites or computers, that promised to transform society. Later, observers recognized that even more important were the social and technical processes merging telecommunications and computerization into networks for the movement and manipulation of symbols, just as transportation networks had done previously for raw materials, labor, and manufactured goods (Castells, 1996). The information infrastructure is increasingly cast as the new key technology and master metaphor for society (Graham \& Marvin, 1996; Star, 1997).

The communication ideology, then, is at work across society: in the corporate and government rhetoric associated with expanding telecommunication networks, such as the promotion of the information superhighway via corporate mergers (e.g., Gore, 1991); in the speculations of progressive social critics who see new technologies as the means for recapturing a sense of community or political mobilization (e.g., Rheingold, 1993); and in our interpersonal interactions, where communication is considered the key mechanism of positive racial, gender, class, family, or work relations.

\section{Simulation/Spectacle as Sources of Information}

The first characteristic of interaction that reflects the communication ideology is that simulation and spectacle have become dominant modes or sources of information, and so have subtly changed the ways that people understand and talk about what is "true" (Postman, 1992). Baudrillard (1983, 1987), Eco (1986), Debord (1995), and others have noted a related phenomenon, "hyperreality." "It is the generation of models of a real without origin or reality: a hyperreal" (Baudrillard, 1983, p. 2). Both simulation and spectacle (and their relative, hyperreality) are elements of "virtuality." While simulation generates representations that may or may not be grounded in physical experience, spectacle elevates "real" events, expanding their symbolic meaning and significance by heightening their visual appeal and the size of the audience.

Poster (1990) argues that interaction via electronic media is dominated by "informationalsimulations." "Realistic-looking" effects, locations, movements, and so forth are fabricated entirely using computer imaging, which itself is based on models of objects and their relations that may bear little resemblance to ordinary "real" objects or relations. Drawing on Heidegger's notion of thrownness in an analysis of virtual reality technologies and simulations in architecture, Coyne (1994) notes the tendency of virtual reality (VR) designers to stress a high degree of detail and conformity to real-world models, despite the fact that such literalness is not always needed for effective or meaningful representations. In other contexts, scientists no longer need to observe natural events (e.g., weather, financial markets, biological evolution, social networks) to analyze or understand them. Instead, it is cheaper and faster to model complex events by submitting selected variables to computational manipulation to create a simulation that can be studied at the researcher's convenience. ${ }^{3}$ In short, knowledge (even scientific knowledge) is increasingly derived from what were once thought of as imaginary or fantastic situations, but now are deliberately designed, fabricated, and presented as plausible alternatives to "reality."

Many recent analyses of computer-mediated interaction and discourse focus on the simulation of physical features, identity, spaces, and things in virtual social settings. Researchers have described the experiences of MUD participants in meticulous detail: how they adopt "avatars" or create other alternative identities, "move" through imaginary places, and interact with other actors whose fantastic features and meanings are carefully interpreted. Stone (1995) describes the elaborately furnished environment of Fujitsu's Habitat, in which avatars can change body parts and gender as well as clothes (in contrast to the starkly unadorned environments offered by commercial on-line service providers, which she calls "the Motel 6 of virtual systems"; Stone 1995, p. 69). Likewise, system users can simulate or "play" with alternative identities - whether in the relatively weak form of e-mail aliases or the strong form of invented characters (Turkle, 1984, 1996). Several studies have examined cases in which characters engaged in activities that would be considered deviant in "real world" situations, such as rape (Dibbell, 1996) or gender switching. Other cases have been reported in which system users invented and presented whole personae that other participants believed were real people, like "Julie Graham" (Stone, 1995).

Clearly, simulation is considered to be a definitive feature of virtual reality and interaction. However, spectacle is also involved, though it is more often associated with conventional media like film or television. Though we might hesitate to call them "real," nonsimulated events in the "real world" must take on a larger-than-life scale to get attention at all: they must be spectacular. Likewise, virtual events and interactions can rise to the level of spectacle, and may provide the same kind of spectacular experience for "viewers." The "Julie Graham" episode took on a spectacular quality as more people got to know "Julie's" 
story while her creator spun a melodramatic story for a growing and sympathetic on-line community/audience. A different example can be seen in the NASA/Jet Propulsion Laboratories' World Wide Web site, which relayed minute-by-minute updates and pictures from the Mars lander and Sojourner Truth rover in July 1997. The site itself became a spectacular source of news and even cutaway video shots for conventional cable and print media coverage.

Baudrillard argues that the main form of response to spectacle is watching, not necessarily acting or participating in the event. Indeed, he notes that perhaps the only powerfulor meaningfulresponse is passive-not watching -because there is little effective opportunity for audience members to stage or fabricate alternative spectacles of their own. Dayan and Katz (1992), in their discussion of classic examples of spectacle that they call media events, take a more positive view and claim that watching such staged events is a new kind of social or political participation on a larger scale than has been possible historically. Virtual social forms may add a new dimension, since systems not only give users unprecedented ability to "see," but also the choice of whether to create "counterspectacles" of their own.

One of the main implications of the growing reliance on spectacle and simulation is that they modify cultural ideas about truth and falsity. Virtuality implies a constructed reality, without reference to truth or falsity in the traditional sense. Baudrillard (1983) points out that the word "simulation" (as in "simulated pearls") has conventionally implied something false or faked (just as "virtual" has conventionally meant an approximation or almost, as in "virtually complete"). Flussser (1996) notes that we tend to distrust alternative (virtual) worlds because they are made and not given. By and large, however, people perceive most of the on-line world, from chatroom interactions to web pages, as "true," though it is often difficult to ascertain the accuracy or even the source of much Web-based information (as librarians point out, it has poor "authority control").

In this context, it is not surprising when people resort to defining truth in more personal ways, as belief shared by "me and my closest friends and family." As a result, they may withdraw to smaller and smaller spheres of interaction, both face-to-face and mediated, where they can be sure that others share their special meanings and biases.

\section{Exhibitionism/Voyeurism as a Communicative Style}

The second characteristic of interaction and discourse related to the communication ideology is the use of exhibitionism and voyeurism as styles of expression. Baudrillard (1987) refers to this phenomenon as obscenity, seeing what should not be seen. In contemporary culture, the revelation of private and personal information has become a normal aspect of communication, as people want to be perceived as accessible and open. Those who are protective or reluctant to disclose information about themselves are often negatively labeled as dishonest or hiding something.

The atmosphere of voyeurism or obscenity is crystallized in talk shows and "reality-based" TV, which feature personal problems or police/ambulance calls on hapless and otherwise anonymous citizens who are presented at their worst. It is an undercurrent of many virtual social environments like MUDs or MOOs, where we may "watch" other characters' interactions, even their simulated intimacies. There is also a voyeuristic connotation in the term we use for members of listservs or discussion groups who do not contribute to the conversation, but instead only read others' messages_- "lurkers."

This prevailing atmosphere, however, has to some extent precipitated a privacy backlash among people who have the economic and technical means to erect stronger boundaries between their private lives and others' invasive demands for personal information. Telecommunication and computer technologies can give us the means to exclude others as well as to reach them (e.g., via caller ID, caller ID blocking, answering machines or voice mail, computer e-mail aliases, cable channel blocks). Jones (1995), commenting on Ross (1990), notes that the "fervor" surrounding data encryption and PGP indicates the extent to which privacy has become a key issue for users of computer-based systems and media. Similar concerns underlie the adoption of web filters by public libraries in response to parents' demands that their children be prevented from gaining access to certain types of on-line content. Recently the American Library Association issued a policy statement rejecting the use of web filters in public libraries, on the grounds that such use violates the spirit of the 1997 U.S. Supreme Court ruling overturning the Communications Decency Act.

When personal revelation becomes the norm, new adaptations may evolve for people who traditionally have been exempt from disclosure or who find it uncomfortable (adult males, authority figures) (e.g., sensitivity training, counseling, participatory management techniques). Or people may simply withdraw from communication situations that require self-disclosure. For example, fewer citizens may run for public office if it necessitates the revelation of everything from tax, medical, and educational records to personal friendships - regardless of whether the information bears on their qualifications for office. A more elaborate tactic might be to invent or change an on-line identity, so that we can protect our "real" personal information while disclosing the most intimate details about the lives and experiences of alternative, virtual selves. 


\section{Awareness of Surveillance}

A third feature of communication-ideological interaction and discourse is people's growing sense of being under surveillance, and shaping their self-presentation accordingly. Giddens $(1984,1990)$ argues that surveillance activities characterize modern societies. Gandy (1993) expands on this view and Foucault's concept of panopticism to argue that information technologies help reproduce and reinforce the modern sense of being watched, to the point that individuals modify their behavior unconsciously. He calls this self-monitoring behavior "the panoptic sort."

The growing awareness of surveillance, made ubiquitous through the use of ICTs (Bogard, 1996), is based in our common experience of surrendering all kinds of personal and economic information on demand under the threat of being denied essential services like health care, housing, or credit (Laudon, 1986). This information is then commonly shared with other institutions, often without our knowledge or explicit consent, for purposes other than those for which the information was originally demanded. Accordingly, we modify our behavior, making personal choices and presenting ourselves to others in ways that conform with what we assume to be the expectations of those requesting the information(e.g., banks, insurance companies, the IRS or state tax agencies, other governmental bodies, creditors).

It reasonably follows that we may may try to control the terms of engagement with the "watching" institutions. Giddens (1990) describes individuals as "knowledgeable agents" able to respond to surveillance. Lyon (1994) and Lyon and Zureik (1996) caution against seeing surveillance entirely in a negative light and suggest that people can use ICTs themselves for countersurveillance. Electronic commerce and commercial uses of the World Wide Web have met considerable consumer resistance, which may indicate that users understand the privacy and security risks of sending personal identification or credit information over the Internet. And as more of us learn (often to our dismay) that our web browsers leave traceable identifying information, called "cookies," at each site we visit on-line, we try to "turn off" or disable this function in the browser software.

Alternatively, control may take the form of withdrawal, as noted already for self-disclosure, or as rationalization, that is, when we justify our compliance with demands for information "because otherwise they wouldn't give me the mortgage," "because they'd audit me." A classic example is the job prospect who submits to urine drug testing though it may be humiliating and even irrelevant to performance, in exchange for work when jobs are scarce. Via rationalization, we can feel that we have at least maintained some degree of choice in a social situation where we may in fact have little influence.

\section{INSTRUMENTAL RATIONALITY/SELF-INTEREST}

Alongside the communication ideology, a contrasting idea in contemporary culture also influences people's interaction and social discourse. Even those of us who communicate openly and honestly have competing interests and conflicts, which can become exacerbated as consumer culture, political disenchantment, economic uncertainty, and individually targeted media encourage us to focus on our personal situations, desires, and experiences at the expense of our social and community ties (Gitlin, 1995). Several writers have asked what the notion of "community" means when a substantial proportion of social interaction is conducted on-line. Jones (1995) provides the best overview of this body of work, though he (like many of those he cites) finds no clear answer to the question.

It seems clear that the individualism and Weberian instrumental rationality that were such influential features of modernity continue to flourish in contemporary culture. Analysts have noted the growing tendency of people to segregate themselves into ever smaller communities of interest rather than to participate in more pluralist activities like political parties, large religious congregations, or social clubs (Lasch, 1978; Wuthnow, 1994; Putnam, 1995). Social differentiation, they argue, and not integration, marks society today, even to the point of breaking down the "public sphere," a modern social formation mediating between the private realm and the state (Elliott, 1986; Habermas, 1974, 1989). The modern "public" cannot exist without a shared arena for interaction among groups with different interests - a function that has been performed, if inconsistently, by the mass media.

Though critics have charged that the "public sphere" is an idealization, and that the mass media have tended to serve elite interests, others now worry that even that arena is being eclipsed by increasingly narrow niche media. A sense of alienation and dissatisfaction is broadly reported (Postman, 1992; Hughes, 1993; Gitlin, 1995). Even the most developed societies have experienced disruptive fragmentation among groups with contrasting beliefs, ethnic backgrounds, cultural heritages, and economic resources. In reaction, social elites sensing their declining influence strive to reclaim and hold a high/canonical culture base against the incursions of multiculturalism.

In contrast, Hondrich (1992) believes that social differentiation into "niche societies" is a positive evolutionary trend that spreads risk across social groups instead of concentrating it in the single world society. Bell (1973, 1979, 1980) may have anticipated the discursive style associated with differentiation and self-interest in the "games between persons" he predicted for postindustrial society.

In general, the longstanding modernist tension seems to be tightening between the tendency toward social 
integration, cultural assimilation, and traditional norms of community, like that associated with industrial mass or world society, and the tendency toward social differentiation and cultural diversity like that associated with niche or tribal societies (depending on whether one takes the post- or premodern view of the second tendency, respectively). Again, we can look for evidence of instrumental rationality in people's interactions and discourse.

\section{Competitive Use of the Knowledge "Commodity" and Communication}

The widespread assumption that information/knowledge is or should be treated as a commodity encourages individuals and groups to acquire and use it competitively, as they would any other commodity. The common understanding of information has shifted from freely attainable knowledge to a tradable good with monetary value (e.g., Branscomb, 1985; Buckland, 1991). This is not a new development (societies have always treated certain kinds of information in certain situations as economic goods), and many researchers and policy analysts continue to point out the problems inherent in commodification (e.g., one can sell information but still own it, unlike other commodities). However, in everyday life we increasingly view information and even communication in terms of economic exchange, not social relationship, value. Communication has become one more form of trade in a "market" where information is the commodity. It is natural in this framework for us to use communication and information (and the associated technologies) competitively to maximize our personal advantage, instead of collaboratively to share meaning and reinforce social ties. Commodification fosters competition, which may ironically lead us to disengage with others selectively and strategically, lest they gain an unreciprocated advantage.

Globalism/Parochialism. The global frame of reference that many people espouse may in fact mask a deeper separatism or parochialism. The interconnectedness or "global village" idea is a popular one, not just as an economic strategy but as a political world view, dating back at least to McLuhan (1964), which emphasizes the commonalities among cultures and the merits of electronic communication as a cultural bridge.

However, globalism may be a superficial phenomenon for most people. Using new electronic media and ICTs, we may witness events globally, but still act as locally as ever - whether our localities are of geography, education, ethnicity, religion, expertise, language, work, or leisure. We seek to distinguish ourselves from each other and reject the "melting pot" metaphor, though we want to see how others live. Technological networks are often considered to be intrinsically homogenizing because of their potential reach, echoing earlier beliefs about mass media. However, because they also employ powerful switching capacity, they have allowed us to segregate ourselves more effectively and finely than ever before.

Members of new social movements, the vanguard of differentiation, no longer find it necessary to secure the support of (and to compromise with) large publics in order to achieve their goals. Small groups can organize via e-mail networks, direct mail, or fax distributions. We use the new media to reach others who share our same specialized interests, to exclude those with different interests, and to avoid encounters with the larger public. That is, we do not need to interact among or mobilize across groups, do not need to face disagreement or the risks of persuasion, in order to find a critical mass of others who share our point of view. We join small on-line chat groups, create alternative personae in virtual cafes, publish personal "zines," update our web pages, and watch specialized cable channels. As Joe Turow notes, "Diversity is being defined by people going in their own little media areas and talking about themselves to each other" (Alderman, 1997).

This contrasts with the usual conceptualization of the larger public as comprised of many small but interacting communities that constitute a collective culture ("melting pot") that is simply reported or reflected in the mass media. A mainstream culture is portrayed in the mass media, though it may be a pastiche of less visible peripheral or niche cultures. The contradiction surfaces in recent social commentary as well-while globalism and multiculturalism are seen by some to be complementary economic phenomena (Rieff, 1993), globalism is viewed by others as a homogenizing threat to local culture that has provoked multiculturalism as a response (Barber, 1995; Gitlin, 1995).

\section{Vertical Versus Lateral Information Inequity}

A third characteristic of discourse under the influence of instrumental rationality, and which follows from surface globalism/deep separatism, is the emergence of multiple forms of information inequity. Conventionally, information inequity is associated with class, income, and education, so that those with greater resources are also assumed to have the greatest access to information, and vice versa (Golding \& Murdock, 1986; D. Schiller, 1988; Braman, 1989; Siefert et al., 1989; Doctor, 1991, 1992). This can be thought of as vertical inequity. However, lateral inequity may also develop when people with similar economic and educational backgrounds differ widely in their access to and use of information, according to their social "niches." Because we can limit our interaction with other groups by using new media technologies, we can avoid exposure to and persuasion by more diverse (i.e., contradictory) types of information. This suggests that 
people who are considered well informed in some ways may in other ways be information "have-nots." As lateral inequities increase, our ability to mobilize effective public action at the whole-society level may decrease, not only because certain groups will not affiliate with each other, but also because some of us will simply not know about issues that are vital to others. We can recall Stehr's point that the "extended capacity to act" enjoyed by individuals and groups is accompanied by a diminishing capacity to act on the part of institutions (Stehr, 1994).

\section{Public Versus Private as Strategies, Not Spaces}

A fourth feature of interaction and discourse based on selfinterest, and stemming from our increased identification with separate niche social groups, is the use of the public versus private contexts as strategies for handling difference or conflict. We relegate noncontroversial information to public communication channels, while we confine our controversial or disputable views to carefully segregated private forums where the possibility of challenge is minimized. Meyrowitz (1985) and others have suggested that media (especially television) blur the line between public and private life and so encourage people to self-disclose inappropriately (i.e., in public situations). However, using networked ICTs, we no longer treat mediated communication as exclusively public and face-to-face communication as exclusively private, and do not violate norms or etiquette when we cross these boundaries. "Public" and "private" today refer to differing strategies for handling difference and potential conflict, no matter what communication channels are used.

Generally, we do not express certain biases, prejudices, or unpopular beliefs (or, if they are expressed, they are rhetorically bracketed as deviant) in a public context or medium (e.g., mass media, or to every member of an organization via e-mail). But we may express and even nurture these same beliefs in what we have come to think of as private media, where we can express such ideas (e.g., MUDs, religious television, talk radio, bulletin boards, fax networks).

At the same time, and paradoxically, our most intimate self-disclosures have become appropriate and usual content in the public mass media (television, print). Perhaps this is because even our most personal revelations (e.g., sexual practices, illness, psychological trauma) are merely titillating or outrageous, and cannot be factually disputed by others, therefore they are safe topics for public airing. Our personal revelations, whether among friends, at work, or on TV, are reassuringly open and communicative. They reinforce the communication ideology and draw large audiences. On the other hand, if someone's claim can be factually disputed or logically argued-for example, whether the Holocaust "really" happened, or whether the
U.S. government deliberately created AIDS - they may be more likely to avoid mass outlets and instead circulate their views in forums where they will be cultivated instead of questioned. As Curry (1996, p. 5) points out, privacy "provides a basis for the maintenance of one's identity" by creating the possibility of a place where we establish and maintain habits and routines. Seen from this perspective, the private sphere, whether face-to-face or virtual, is reinforcing and reassuring.

By using the new media technologies, members of nonmainstream social and cultural groups can express perspectives and values that would be marginalized or invisible in a mass-media-dominated environment. They can extend their spheres of influence far beyond the local geographic community (for testimonials, see Rheingold, 1993). Similar groups occasionally have been able to exert social and political influence that appears to threaten the pluralist values of modern societies (e.g., the rise of fundamentalist Islam or Christianity as political forces that are intolerant of dissent; see Barber, 1995).

At the same time, mass social interests (e.g., broadcasting and publishing corporations, consumer goods manufacturers, marketers and advertisers, and political parties) often ignore or discount such groups and their new uses of technology, for example, by depicting the information superhighway mainly as more channels for delivering information "goods" such as home shopping or movieson-demand to audiences of consumers (Lievrouw, 1994). Mass society institutions try to preserve the familiar centralized structures of mass production and consumption that have buttressed their prosperity and growth. On the other hand, the centrist tendencies of those same institutions have helped to neutralize the influence of extreme or dislocating social and political views, extend the interests of the majority, or even suppress change. Therefore they have been depicted by some observers as inherently democratic (Gurevitch \& Blumler, 1990) or inherently conservative (Exoo, 1987).

Recent legislation, such as the Communications Act of 1996, indicates that federal agencies are anxious to place restrictions on speech via these channels to control divergent or deviant ideas, even when the channels in question are not public (e.g., on-line services) (though, as noted previously, the U.S. Supreme Court has struck down such restrictions in the Communications Decency Act). Historically, regulatory control over content has extended only to those media that the government actually licensed in the name of the public interest because of their presumed natural scarcity (i.e., broadcasting). Now there are moves to regulate media that are neither scarce nor licensed, where there is not a clear public interest stake in the content they carry. Whether by social segregation or government regulation, the current zeitgeist prompts us to control the expression of controversial ideas. 
The characteristics of interaction and discourse associated with the communication ideology and instrumental rationality/self-interest - the elements that comprise heterotopic communication - can be summarized: On one hand, we increasingly seek information from simulation and spectacle; we express ourselves in an exhibitionistic/voyeuristic style, and our interactions and selfpresentation are influenced by our sense of surveillance or being watched. On the other hand, we acquire and use information competitively, treating communication as a commodity exchange; we adopt an outward perspective of globalism while practicing a kind of electronic separatism, creating many small and specialized channels for interaction with others who share our particular beliefs; we share less and less general knowledge with different people or groups; and we tend to present incontestable information via large shared channels and our more controversial beliefs via specialized channels.

At the most general level, heterotopic communication allows us to communicate our differences. We can convey our openness and willingness to disclose or "share" while preserving a private or backstage domain of separate interests or beliefs that is resistant to persuasion. By engaging in heterotopic communication, we can avoid the appearance of conflict in a social milieu populated by many divergent and even opposing interests. While we have the sense of being seen, heterotopic communication via new media also gives us the power to "see" others and control what they see of us.

So a contradiction exists: Social life, by definition, is enacted in groups whose members share certain interests. Our joint actions are based on the assumption that shared interests "naturally" outweigh or are more beneficial than individual interests. Certainly, some balance between self-interest and shared interest has long been recognized as a basic necessity of social behavior.

Yet today many of us have an unprecedented ability to define and communicate our personal priorities, needs, and perceptions using new media technologies. Through heterotopic communication we can routinely avoid overt (public) disagreement and can easily segregate ourselves away from the mass and into ever smaller communities of interest. The ideal is to appear communicative while advancing one's particular interests. We may use certain prosocial and normative kinds of communication behavior, such as honesty or self-disclosure, in this context to advance our personal or local advantage. Self-interest can overthrow the traditional self-interest/shared interest balance, even as we retain the appearance of communication and cooperation. Our communicative actions conceal and allow us to avoid opposition and conflict. Communication and information technologiescan help both ways, enabling us to make contact and communicate with others, but also, critically, to exclude or screen encounters with other people or messages. The source of this sensibility may be modernity itself; Gouldner notes "the schismatic character of modern consciousness: its highly unstable mixture of cultural pessimism and technologicaloptimism" (1990, p. 313).

\section{HYPOTHESIZING HETEROTOPIC COMMUNICATION}

The observations offered in this essay only begin to suggest the possible contours of interaction and discourse in information culture. They also seem to contradict some of the expansionist, progressive, or homogenizing visions that are frequently associated with claims about information society. Informational or virtual culture may not just be a matter of "everything all the time," of information overload or endless access or homogenization. Individuals use information resources and technologies in ingenious displays of strategic self-interest, multicultural differentiation, and resistance to persuasive mass appeals. People may have more informational choices than ever before, but they monitor and limit their interests closely and tend to select information that conforms generally to their existing prejudices and world views. The legacy of modernism is seen in the monocultural assumptions about equity, universalism, rationality, or individualism played out in the mass media, but single-issue politics, religious and ethnic separatism, and preoccupation with claims of moral superiority or "victim" status pervade our multicultural, separate discourses.

The discussion presented here suggests a series of hypotheses for exploration in future research:

- As reliance on spectacle and simulation for information increases, notions of "truth" and "falsity" may become more fragmented.

- As discourse becomes more exhibitionist/voyeuristic (i.e., is legitimized by self-disclosure), individuals may resort to using personal "spaces" and representations made possible by new ICTs (e.g., the creation of alters or avatars in on-line chat rooms, personal Web sites).

- As individuals become more aware of surveillance and the pressure to adapt their behavior to conform with surveilling institutions' expectations, they may try to control the level or type of engagement with such institutions using new ICTs.

- Increased commodification of knowledge/information will encourage increased competitive uses of information, rather than increased information sharing, and so will tend to exacerbate both vertical and lateral information inequity.

- As lateral information inequities increase, the potential for movements or mobilization across diverse social groups decreases. 
- Vertical information inequities are associated with the bifurcated use of different media as information sources: Those with greater resources will grow to rely more on new network-based information sources, while those with fewer resources will continue to depend on conventional mass media sources.

- The greater the reliance on mass/public media, the more mainstream (noncontroversial) the content; the greater the reliance on networked/private media, the more "fringe" the content may become, targeted to small groups of sympathetic recipients.

- As globalism is adopted as a political/economic/ cultural strategy or framework, there is a parallel rise in interest in local, single-issue, narrowly defined interest groups and networks that may be supported by new ICTs.

Heterotopic communication is by no means a fully developed framework, but perhaps a reconsideration of our interactions and discourse from this perspective will reveal that the information society is neither entirely utopic nor dystopic - neither is it a wholly "new society," nor is it merely revived industrialism. More development of these ideas, and their empirical application, may help sort out the complexity.

\section{NOTES}

1. The informationsociety is consideredhere to be a socialformation involvingnumerous largetechnicalsystems (LTSs), especiallytelecommunication and information systems, although it embodies much more than technologies alone. In John Law's words, it is emergent, having "attributes possessed by none of its individual components" (Law, 1987, p. 115). It is a cultural work-in-progress, more than the sum of its technologicaland economic parts.

2. Robert Hughes (1993) has identified an analogous belief in the enlightening power of art, which he calls the "therapeutic fallacy."

3. The choices involved in modeling, as well as system design, pose ethical problems for technologies such as global information systems (GISs) (e.g., Curry, 1994, 1995).

\section{REFERENCES}

Alderman, J. 1997. Battling info barbarians at the gate. Wired News, May 1. [http://www.wired.com]

Alexander, J. 1992. The promise of a cultural sociology: Technological discourseand the sacred and profane information machine. In Theory of culture, eds. R. Munch and N. J. Smelser, pp. 293-323. Berkeley, CA: University of California Press.

Bakhtin, M. M. 1981. The dialogic imagination, ed. M. Holquist, trans. by C. Emerson and M. Holquist. Austin, TX: University of Texas Press.

Barber, B. R. 1995. Jihad vs. McWorld. New York, NY: Times Books/Random House.
Baudrillard, J. 1983. Simulations, trans. P. Foss, P. Patton, and P. Beitchman. New York: Semiotext(e).

Baudrillard, J. 1987. The Ecstasy of Communication, trans. B. Schutze and C. Schutze. New York: Semiotext(e).

Bell, D. 1973. The coming of post-industrial society: A venture in social forecasting. New York: Basic Books.

Bell, D. 1976. The cultural contradictions of capitalism. New York: Basic Books.

Bell, D. 1979. A social framework of the information society. In The computer age: A twenty-year view, eds. M. L. Dertouzos and J. Moses, pp. 163-211. Cambridge, MA: MIT Press.

Bell, D. 1980. The social framework of the information society. In The microelectronics revolution, ed. T. Forester, pp. 500-549. Cambridge, MA: MIT Press.

Beniger, J. 1986. The control revolution: Technological and economic origins of the information society. Cambridge, MA: Harvard University Press.

Berleur, J., Clement, A., Sizer, R., and Whitehouse, D., eds. 1990. The information society: Evolving landscapes. New York: SpringerVerlag.

Bogard, W. 1996. The simulation of surveillance: Hypercontrol in telematic societies. Cambridge: Cambridge University Press.

Braman, S. 1989. Defining information. Telecommunications Policy 13:233-242.

Branscomb, A. 1985. Property rights in information. In Information technologiesand social transformation, ed. B. R. Guile, pp. 81-120. Washington, DC: National Academy Press.

Buckland, M. K. 1991. Information as thing. Journal of the American Society for Information Science 42(5):351-360.

Calhoun, C. 1991. Indirect relationships and imagined communities: Large-scale social integration and the transformation of everyday life. In Social theory for a changing society, eds. P. Bourdieu and J. S. Coleman, pp. 95-121. Boulder, CO: Westview Press.

Calhoun, C. 1992. The infrastructure of modernity: Indirect social relationships, information technology, and social integration. In Social change and modernity, eds. H. Haferkamp and N. J. Smelser, pp. 205-236. Berkeley, CA: University of California Press.

Carey, J. W. 1989. Communication as culture: Essays on media and society. London: Unwin Hyman.

Castells, M. 1989. The informational city: Information technology, economic restructuring, and the urban-regional process. Oxford: Basil Blackwell.

Castells, M. 1996. The rise of the network society. Oxford: Blackwell.

Cherry, C. 1985. The age of access: Information technologyand social revolution: Posthumous papers of Colin Cherry. London: Croom Helm.

Coyne, R. 1994. Heidegger and virtual reality: The implications of Heidegger's thinking for computer representations. Leonardo 27(1): 65-73.

Curry, M. R. 1994. Image, practice and the hidden impacts of geographic information systems. Progress in Human Geography 18(4):441-459.

Curry, M. R. 1995. Rethinkingrights and responsibilitiesin geographic information systems: Beyond the power of the image. Cartography and Geographic Information Systems 22(1):58-69.

Curry, M. R. 1996. Privacy, Property and the Primacy of Place. Unpublished manuscript, Department of Geography, University of California, Los Angeles. 
Dayan, D., and Katz, E. 1992. Media events: The live broadcasting of history. Cambridge, MA: Harvard University Press.

Debord, G. 1995. The society of the spectacle, trans. D. NicholsonSmith. New York: Zone Books. (Original publication 1967, La Societe du spectacle, Buchet-Chastel.)

Dibbell, J. 1996. Taboo, consensus, and the challenge of democracy in an electronic forum. In Computerization and controversy: Value conflicts and social choices, (2nd ed.) ed. R. Kling, pp. 552-568. San Diego, CA: Academic Press. (Article originally appearedas "A Rape in Cyberspace or How an Evil Clown, a Haitian Trickster Spirit, Two Wizards, and a Cast of Dozens Turned a Database into a Society," Village Voice, December 21, 1993, pp. 36-42.)

Doctor, R. D. 1991. Information technologies and social equity: Confronting the revolution. Journal of the American Society for Information Science 42(3):216-228.

Doctor, R. D. 1992. Social equity and informationtechnologies: Moving toward information democracy. In Annual review of information science and technology, vol. 27., ed. M. E. Williams, pp. 43-96. Medford, NJ: Learned Information, for the American Society for Information Science.

Doheny-Farina, S. 1996. The wired neighborhood. New Haven, CT: Yale University Press.

Druckrey, T. 1996. Introduction. In Electronic culture: Technology and visual representation, ed. T. Druckrey, pp. 12-25. New York: Aperture.

Dutton, W. H., Blumler, J. G., and Kraemer, K. L., eds. 1987. Wired cities: Shaping the future of communications. Boston: G. K. Hall.

Eco, U. 1986. Travels in hyperreality. San Diego, CA: Harcourt Brace Jovanovich.

Elliott, P. 1986. Intellectuals, the "information society" and the disappearance of the public sphere. In Media, culture and society: A critical reader, eds. R. Collins, J. Curran, N. Garnham, P. Scannell, P. Schlesinger, and C. Sparks, pp. 105-117. London: Sage.

Euske, N. A., and Roberts, K. H. 1987. Evolving perspectives in organization theory: Communication implications. In Handbook of organizational communication: An interdisciplinary perspective, eds. F. M. Jablin, L. L. Putnam, K. H. Roberts, and L. W. Porter, pp. 41-69. Newbury Park, CA: Sage.

Exoo, C. F. 1987. The bias of the news. In Democracy upside down: Public opinion and cultural hegemony in the United States, ed. C.F. Exoo, pp. 73-106. New York: Praeger.

Flusser, V. 1996. Digital apparation. In Electronic culture: Technology and visual representation, ed. T. Druckrey, pp. 242-246. New York: Aperture.

Foucault, M. 1986. Of other spaces. Diacritics 16(1):22-27.

Gandy, O. H., Jr. 1993. The panoptic sort: A political economy of personal information. Boulder, CO: Westview Press.

Garnham, N. 1990. Capitalism and communication: Global culture and the economics of information. London: Sage.

Garnham, N. 1994. Whatever happened to the information society? In The management of information and communication technologies: Emerging patterns of control, ed. R.E. Mansell, pp. 42-51. London: Aslib, The Association for Information Management.

Gergen, K. 1991. The saturated self: Dilemmas of identity in contemporary life. New York: Basic Books.

Giddens, A. 1984.The constitutionof society. Berkeley,CA: University of California Press.

Giddens, A. 1990. The consequences of modernity. Stanford, CA: Stanford University Press.
Gitlin, T. 1995. The twilight of common dreams: Why America is wracked by culture wars. New York: Metropolitan Books/Henry Holt and Co.

Golding, P., and Murdock, G. 1986. Unequal information: Access and exclusion in the new communications marketplace. In New communication technologies and the public interest, ed. M. Ferguson, pp. 71-83. Beverly Hills, CA: Sage.

Gore, A. 1991. Infrastructurefor the globalvillage. Scientific American 265(3):150-153.

Gouldner, A. 1990. Ideology, the cultural apparatus, and the new consciousness industry. In Culture and society: Contemporary debates, eds. J. C. Alexander and S. Seidman, pp. 306-316. Cambridge: Cambridge University Press. (Excerpted from The dialectic of ideology and technology. New York: Seabury Press, 1976.)

Graham, S., and Marvin, S. 1996. Telecommunications and the city: Electronic spaces, urban places. London: Routledge.

Gurevitch, M., and Blumler, J. G. 1990. Political communication systems and democratic values. In Democracy and the mass media, ed. J. Lichtenberg, pp. 269-289. Cambridge: Cambridge University Press.

Habermas, J. 1974. The public sphere. New German Critique 1(3):4955.

Habermas, J. 1983. Modernity-An incomplete project. In The antiaesthetic: Essays on postmodern culture, ed. H. Foster, pp. 3-16. Port Townsend, WA: Bay Press.

Habermas, J. 1989. The structural transformation of the public sphere. Cambridge, MA: MIT Press.

Haferkamp, H., and Smelser, N. J. 1992. Introduction.In Socialchange and modernity, eds. H. Haferkamp and N. J. Smelser, pp. 1-36. Berkeley, CA: University of California Press.

Hall, S. 1986. Cultural studies: Two paradigms. In Media, culture and society: A critical reader, eds. R. Collins, J. Curran, N. Garnham, P. Scannell, P. Schlesinger, and C. Sparks, pp. 34-48. London: Sage. Hepworth, M., and Robins, K. 1988. Whose information society? A view from the periphery. Media, Culture and Society 10:323-343.

Hondrich, K. O. 1992. World society versus niche societies: Paradoxes of unidirectional evolution. In Social change and modernity, eds. H. Haferkamp and N. J. Smelser, pp. 350-366. Berkeley, CA: University of California Press.

Hughes, R. 1993. Culture of complaint: The fraying of America. New York: Oxford University Press.

Innis, H. A. 1950. Empire and communications. Oxford: Oxford University Press.

Jones, S. G. 1995. Understandingcommunity in the informationage. In Cybersociety: Computer-mediated communication and community, ed. S. G. Jones, pp. 10-35. Thousand Oaks, CA: Sage.

Klapp, O. E. 1986. Overload and boredom: Essays on the quality of life in the information society. New York: Greenwood Press.

Lasch, C. 1978. The culture of narcissism: American life in an age of diminishing expectations. New York: Norton.

Laudon, K. 1986. Dossier society: Value choices in the design of national information systems. New York: Columbia University Press.

Law, J. 1987. Technology and heterogeneous engineering: The case of Portuguese expansion. In The social construction of technological systems, eds. W. E. Bijker, T. P. Hughes, and T. Pinch, pp. 111-134. Cambridge, MA: MIT Press.

Lievrouw, L. A. 1994. Information and democracy: Understanding the paradox. Journal of the American Society for Information Science 45(6), July:350-357. 
Lyon, D. 1988. The information society: Issues and illusions. Cambridge: Polity Press.

Lyon, D. 1994. The electronic eye: The rise of surveillance society. Cambridge: Polity Press.

Lyon, D., and Zureik, E. 1996. Surveillance, privacy and the new technology. In Computers, surveillance and privacy, eds. D. Lyon and E. Zureik, pp. 1-18. Minneapolis, MN: University of Minnesota Press.

Machlup, F. 1962. The production and distribution of knowledge in the United States. Princeton, NJ: Princeton University Press.

Masuda, Y. 1981. The information society as post-industrial society. Bethesda, MD: World Future Society.

McLuhan, M. 1964. Understanding media: The extensions of man. New York: Mentor.

Meyrowitz, J. 1985. No sense of place. New York: Oxford University Press.

Mosco, V., and Wasko, J., eds. 1988. The political economy of information. Madison: University of Wisconsin Press.

Nora, S., and Minc, A. 1980. The computerization of society: A report to the President of France. Cambridge: MIT Press.

Porat, M. U., and Rubin, M. R. 1977. The information economy (9 vols.). Washington, DC: U.S. Department of Commerce, Office of Telecommunications (OT Special Publication 77-12).

Poster, M. 1990. The mode of information: Poststructuralismand social context. Chicago: University of Chicago Press.

Postman, N. 1992. Technopoly. New York: Vintage Press.

Putnam, R. D. 1995. Bowling alone: America's declining social capital. Journal of Democracy 6(1):65-78.

Rheingold, H. 1993. The virtual community: Homesteading on the electronic frontier. Reading, MA: Addison-Wesley.

Rieff, D. 1993. Multiculturalism's silent partner: It's the newly globalized consumer economy, stupid. Harper's 287(1719): 62-72.

Robins, K., and Webster, F. 1988. Cybernetic capitalism: Information, technology, everyday life. In The political economy of information, eds. V. Mosco and J. Wasko, p. 7. Madison: University of Wisconsin Press.

Rogers, E. M. 1994. Ahistory of communicationstudy: ABiographical approach. New York: Free Press.

Ross, A. 1990. Hacking away at the counterculture. Postmodern Culture $1(1): 1-43$.

Schement, J. R., and Lievrouw, L. A. 1987. A third vision: Capitalism and the industrial origins of the information society. In Competing visions, complex realities: Social aspects of the information society, eds. J. R. Schement and L. A. Lievrouw, pp. 33-46. Norwood, NJ: Ablex.
Schiller, D. 1988. How to think about information. In The political economy of information, eds. V. Mosco and J. Wasko, pp. 27-43 . Madison: University of Wisconsin Press.

Schiller, H. I. 1987. Who knows: Information in the age of the Fortune 500. Norwood, NJ: Ablex.

Shenk, D. 1997. Data smog. New York: Harper Edge.

Shields, P. R., and Samarajiva, R. 1993. Competing frameworks for research on information-communication technologies and society: Toward a synthesis. In Communication yearbook 16, ed. S. Deetz, pp. 349-380. New Brunswick, NJ: Transaction, for the International Communication Association.

Siefert, M., Gerbner, G., and Fisher, J. 1989. The information gap: How computers and other new communication technologies affect the social distribution of power. New York: Oxford University Press (Reprint of a special issue of Journal of Communication).

Slack, J. D., and Fejes, F. 1987. The ideology of the information age. Norwood, NJ: Ablex.

Star, S. L. 1997. A good infrastructure is hard to find. Paper presented to the Department of History and Department of Library and Information Science, University of California, Los Angeles, January.

Stehr, N. 1994. Knowledge societies. London: Sage.

Stehr, N., and Ericson, R. V. 1992. The culture and power of knowledge in modern society. In The culture of power and knowledge: Inquiries into contemporary societies, eds. N. Stehr and R. V. Ericson, pp. 3-19. New York: W. De Gruyter.

Stone, A. R. 1992. Will the real body please stand up? Boundary stories about virtual cultures. In Cyberspace: First steps, ed. M. Benedikt, pp. 81-118. Cambridge, MA: MIT Press.

Stone, A. R. 1995. The war of desire and technology at the close of the mechanical age. Cambridge, MA: MIT Press.

Tehranian, M. 1990.Technologiesof power: Informationmachines and democratic prospects. Norwood, NJ: Ablex.

Turkle, S. 1984. The second self: Computers and the human spirit. New York: Simon \& Schuster.

Turkle, S. 1996. Constructions and reconstructions of the self in virtual reality. In Electronic culture: Technology and visual representation, ed. T. Druckrey, pp. 354-365. New York: Aperture. (Originally published in Mind, Culture and Activity 1(3), summer 1994.)

Webster, F. 1995. Theories of the information society. London: Routledge.

Williams, F., Williams, V., and Phillips, A. F. 1987. Educating the computer generation. In Competing visions, complex realities: Social aspects of the information society, eds. J. R. Schement and L. A. Lievrouw, pp. 49-67. Norwood, NJ: Ablex.

Winner, L. 1977. Autonomous technology: Technics-out-of-controlas a theme in political thought. Cambridge, MA: MIT Press.

Wuthnow, R. 1994. Sharing the journey. New York: Free Press. 